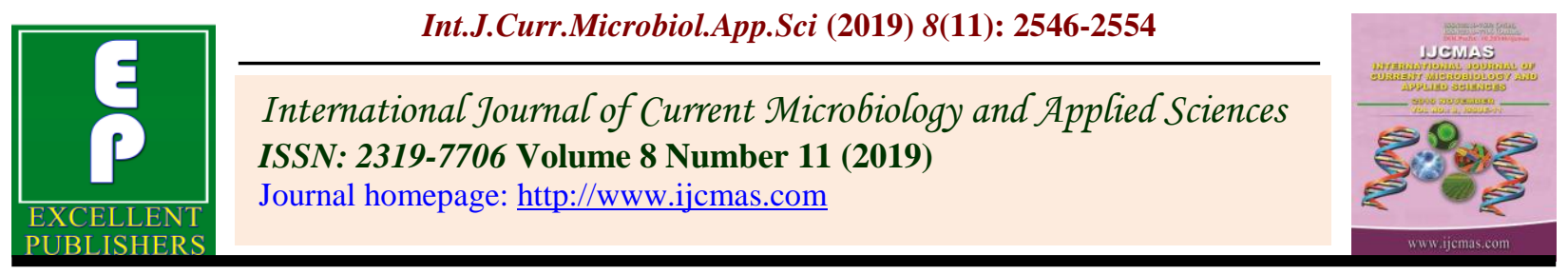

Original Research Article

https://doi.org/10.20546/ijcmas.2019.811.294

\title{
Assessment of Changes in Various Chemical Properties during Decomposition of Crop Residues
}

\author{
Priyanka N. Daphal*, P.W. Deshmukh and Rahul J. Patil
}

Department of soil Science \& Agriculture Chemistry, Dr. PDKV Akola (MH) 444104, India

*Corresponding author

A B S T R A C T

Keywords

Glyricidia, Wheat

straw, Shredded

cotton stalk,

sorghum stubbles,

C: N ratio, FYM,

Rock phosphate,

Cow dung

Article Info

Accepted:

26 October 2019

Available Online:

10 November 2019
The present investigation was conducted at Research Farm, Department of Soil Science and Agricultural Chemistry, Dr. Panjabrao Deshmukh Krishi Vidyapeeth, Akola during 2017-18. The six treatments was carried out T1 $100 \%$ Wheat straw, T2 - $100 \%$ Shredded Cotton Stalk, T3 - $50 \%$ Wheat Straw $+50 \%$ Shredded Cotton Stalk, T4 - 40\% Wheat Straw $+40 \%$ Shredded Cotton Stalk $+20 \%$ Glyricidia Leaf, T5-30\% Wheat Straw $+30 \%$ Shredded Cotton Stalk $+20 \%$ Glyricidia Leaf $+20 \%$ Sorghum Stubbles, T6 $-25 \%$ Wheat Straw $+25 \%$ Shredded cotton stalk $+25 \%$ Glyricidia Leaf $+25 \%$ sorghum stubbles. The results was carried out during periodic decomposition of crop residue de3 composition rate is high treatment (T6) $25 \% \mathrm{WS}+25 \% \mathrm{SCS}+25 \%$ Glyricidia Leaf $+25 \%$ sorghum stubbles as compared to other treatments. In T6 treatment $\mathrm{C}$ : $\mathrm{N}$ ratio was lowest observed decomposition of crop residue total $\mathrm{N}, \mathrm{P}, \mathrm{K}$ and $\mathrm{S}$ was high observed.

\section{Introduction}

The growth in the agriculture production is possible only when the soil is in good health. In our country from ancient time organic manures were the main source of plant nutrient for crop growth and development. At that time Farm Yard Manure and crop and animal residues are the main source of soil fertility but it provide very less amount of nutrients. FYM gives $0.5 \% \mathrm{~N}, 0.2 \% \mathrm{P}$ and $0.5 \% \mathrm{~K}$. The conversion of agricultural residues into value-added compost and its incorporation in soil with cheap nutrient sources viz., rock phosphate improves the crops productivity as well as soil quality. In developing countries composting is needed for intermediate farming system which answers the criteria of low cost, low risk, increased output and increased profit, modified and improved technology. In the soft, warm bosom of decaying compost, a transformation from life to death and back again is taking place. Life is leaving the living plants of yesterdays, but in their leaves and stalks pass on their vitality to the coming generations of future 
seasons. Here in a dank and mouldy pile the wheel of life is turning. Organic manures are the life of soil and if neglected the fertility of soil would not be maintained. However organic movement in Indian owes its origin primarily to the work of Sir Albert Howard who believed that a shift from nature's methods of crop production to adoption of newer methods leads to the loss of soil fertility (Howard, 1940). Organic manure treatment was necessary to sustain productivity and to keep the fertilizer related pollution under control. Improved nutrition inresponse to organic manure treatment happened also because of gain in soil physical health and associated enhancement in nutrient utilization.

The conversion to chemical farming was very swift and within few Decades only its side effects are evident. The conversion from conventional to Chemical farming was very swift as a result of development of fertilizer responsive crop varieties after green revolution era. With the advent of synthetic chemical fertilizers and their widespread adoption and use in farming, there has been less reliance upon organic residues as a source of nutrients for plant growth.

Since fertilizer use in India is mostly subsidy driven farmers often use fertilizers indiscriminately. Within few decades the bad effects of chemical fertilizer based agricultural practices on soil and environment have become evident. Current agricultural practices are responsible for soil impoverishment, leading to reduction of organic matter in the agro-ecosystem (Lal, 1998).

\section{Materials and Methods}

With a view to study the "Characterization of enriched compost prepared from different crop residues" the experiment was carried out at Research Farm, Department of Soil Science and Agricultural Chemistry, Dr. Panjabrao
Deshmukh Krishi Vidyapeeth, Akola during 2017-18. During the decomposition of crop residue to use of rock phosphate and wheat straw, shredded cotton stalk, Glyricidia leafs, and sorghum stubbles available at Research Farm, Department of soil science and agricultural chemistry was utilized for preparation of enriched compost. The cotton residues are shredded into small pieces of approximately $2-3 \mathrm{~cm}$ length. For each pit 40 $\mathrm{kg}$ of crop residues were used for preparation of enriched compost, accordingly rock phosphate, PDKV decomposer, elemental sulphur, urea solution and cow dung slurry were added. The six treatment are estimated T1 - $100 \%$ Wheat straw, T2 - $100 \%$ Shredded Cotton Stalk, T3 - 50 \% Wheat Straw $+50 \%$ Shredded Cotton Stalk, T4 $40 \%$ Wheat Straw $+40 \%$ Shredded Cotton Stalk $+20 \%$ Glyricidia Leaf, T5-30\%Wheat Straw $+30 \%$ Shredded Cotton Stalk $+20 \%$ Glyricidia Leaf $+20 \%$ Sorghum Stubbles, T6 $-25 \%$ Wheat Straw $+25 \%$ Shredded cotton stalk $+25 \%$ Glyricidia Leaf $+25 \%$ sorghum stubbles.

Quantity of ingredient added in phosphocompost

Rock phosphate: @ 12\% (120 kg per ton). PDKV decomposer: $1 \mathrm{~kg}$ per ton. Elemental Sulphur: @5\% (50 kg per ton). Urea solution: @1\% (10 kg per ton). Cow dung slurry: @ 1\% (10 kg per ton).

\section{Methodology for preparation of compost}

The enriched compost was prepared by decomposing various crop residues (wheat straw, shredded cotton stalk, glyricidia leaves, and sorghum stubbles), cow dung slurry with rock phosphate, urea, elemental sulphur and PDKV decomposer.

The enriched compost was prepared by pit method. 
Turnings ware given at 15 days interval up to 90 days of decomposing.

After 90 days of decomposing, heaps of enriched compost ware collected at one place as treatment wise and allowed to cure for another 30 days.

Temperature ware recorded at 7 days of interval.

Compost will be watered regularly at 5-7 days of interval so as to maintain moisture content up to $60-70 \%$.

\section{Results and Discussion}

The data on chemical composition of rock phosphate used for investigation is presented in table 1. Result indicate that rock phosphate used for study having $\mathrm{pH} 8.85$ as well as EC is $0.28 \mathrm{~d} \mathrm{Sm}^{-1}$.

It also contains 7.27 per cent phosphorous and $0.40,0.13$ sulphur and potassium respectively. Similar nutrient pattern was reported by Biswas and Narayanasamy (2006) for rock phosphate.

The data on chemical composition of crop residues used for investigation are presented in table 2 .

The wheat straw, cotton stalk, sorghum stubbles and glyricidia used for investigation contains 42.75, 44.02, 46.66 and 38.71 percent total carbon respectively and the total Nitrogen content was $0.48,0.55,0.48$ and 1.19 Percent respectively. However, $\mathrm{C} / \mathrm{N}$ ratio was observed 89, 80, 97 and 33 respectively. The total phosphorous was recorded in $0.25,0.19$, 0.23 and 0.33 percent respectively. The total potassium was noted $0.59,0.61,1.08$ and 1.21 percent respectively. As well as the Sulphur showed $0.12,0.09,0.13$ and 0.16 percent respectively.

\section{Chemical composition of enriched compost at various periodical Stages}

The results pertaining to the periodical changes in $\mathrm{pH}$ during composting prepared from different crop residues are presented in Table 3. Significant changes were observed in $\mathrm{pH}$ values affected by different treatments.

During composting period the $\mathrm{pH}$ values remained declining irrespective of the treatments and the time span. At 15 days of composting, the $\mathrm{pH}$ values ranged between 7.52 to 7.89 which was gradually falls and at 120 days it ranged between7.16 to 7.48. However, slight higher $\mathrm{pH}$ was recorded for cotton stalks as compared to other. At the end of composting, the lowest $\mathrm{pH}$ (7.16) was observed in treatment (T4) i.e. 40\% Wheat Straw $+40 \%$ Shredded Cotton Stalk $+20 \%$ Glyricidia Leaf. The highest $\mathrm{pH}$ (7.48) was noted in treatment (T3) 50\% Wheat Straw $+50 \%$ Shredded Cotton Stalk.

The present findings are in accordance with those of Singh and Amberger (1998). They pointed out that the initial $\mathrm{pH}$ of decomposing straw increased slightly because of addition of cow dung and rock phosphate of high $\mathrm{CaCO}_{3}$, but it decreased gradually with decomposition of organic matter which resulted in the release of organic acids in all treatments.

Results obtained in table 4 revealed that organic carbon content gradually declined from 15 to 120 days of Composting in all treatments.

The total organic carbon content at 15, 30, 60, 90 and 120 days decomposition of various crop residues showed that there was decrease in total organic carbon content during composting as the decomposition proceed from 15 to 120 days. Among the crop residues used the nitrogen content in glyricidia was higher hence, the combination of glyricidia 
leaf along with other crop residues might have degraded carbon due to the stimulating effect of nitrogen on microbial activity during decomposition.

Continuous decrease in organic carbon content during composting was also noticed by Manna et al., (2001), sibi (2011) and Khan and Sharif (2012). Results obtained in table 5 revealed that organic carbon content gradually declined from 15 to 120 days of Composting in all treatments.

The total nitrogen content during the different decomposition stages that is $15,30,60,90$ and 120 days of decomposition. It was observed that the nitrogen content at the initial stages of decomposition. Where, the lower as the completion stages increases there were increase in total nitrogen content by using various combination of crop residues were noted. Where ever the use of glyricidia leaf was incorporated along with different ratio with wheat straw, Shredded Cotton Stalk and sorghum stubbles the increase in total nitrogen content was observed. This effect is might be due to higher concentration of nitrogen in glyricidia leaf.

They found that the total $\mathrm{N}$ content of compost treatments is in increasing trend with increase in decomposition period the similar findings were also reported by Banta and Dev (2009). They stated that addition of microbial inoculants in rock phosphate lead to increase in $\mathrm{N}$ content of mature compost and addition of rock phosphate accelerates the mineralization of N. Similarly, Sibi (2011) concluded that apparent increase in total nitrogen content in compost is not only due to enrichment but also due to the reduction in weight because of decomposition.

Changes in $\mathrm{C}$ : $\mathrm{N}$ ratio during composting process was recorded at various periodical stages and presented in Table 6. The C: $\mathrm{N}$ ratio of the substrate is the most important factor in the process of decomposition. Wider the $\mathrm{C}$ : $\mathrm{N}$ ratio slower will be the decomposition. Viz. Narrower $\mathrm{C}$ : $\mathrm{N}$ ratio attack more rapidly by decomposting microorganisms.

The highest $\mathrm{C}: \mathrm{N}$ ratio i.e. 84.78 at 15 days stage was recorded in the treatment of $100 \%$ shredded cotton stalk.62.92\% C: $\mathrm{N}$ ratio was noticed in the treatment of $100 \%$ wheat straw at 30days decomposition. The significantly lower values (20.94) of $\mathrm{C}$ : $\mathrm{N}$ ratio was obtained in the use of equal quantities of wheat straw, shredded cotton stalk, glyricidia leaf and sorghum stubbles. The decreased in $\mathrm{C}$ : $\mathrm{N}$ ratio with time span might be due to decrease in carbon due to loss of organic carbon through oxidation and simultaneously increase in the total nitrogen.

The results obtained are in confirmative with the investigation done by Banta and Dev (2009), they noticed that the $\mathrm{C}: \mathrm{N}$ ratio at the initiation stages of composting was higher, which was narrow down at maturity of compost.

Results pertaining to the changes in total phosphorous content during Composting at various periodical stages are presented in Table 7.

The range of total phosphorous content varied from 1.69 to 2.05 in various treatments the significantly highest value of total phosphorous content (2.05) is found in $\left(\mathrm{T}_{4}\right)$ $40 \%$ Wheat Straw $+40 \%$ Shredded Cotton Stalk $+20 \%$ Glyricidia Leaf followed by (T6) $25 \%$ Wheat straw $+25 \%$ Shredded cotton stalk $+25 \%$ Glyricidia Leaf $+25 \%$ sorghum stubbles. Significantly lower total phosphorous content (1.69) was observed in $100 \%$ crop residues through shredded cotton stalk. This effect is might be due to the appreciable amount of phosphorous content in the crop residues used. 
Table.1 Chemical composition of rock phosphate used for study

\begin{tabular}{|l|c|}
\hline Parameters & Content $(\mathbf{\%})$ \\
\hline $\mathbf{p H}$ & 8.85 \\
\hline EC $\left(\mathbf{d ~ S m}^{-\mathbf{1})}\right.$ & 0.28 \\
\hline Total phosphorus & 7.25 \\
\hline Sulphur & 0.40 \\
\hline Potassium & 0.13 \\
\hline
\end{tabular}

Table.2 Chemical composition of crop residues used for study

\begin{tabular}{|l|c|c|c|c|c|c|}
\hline Residues & $\mathbf{C}$ & $\mathbf{N}$ & $\mathbf{C} / \mathbf{N}$ & $\mathbf{P}$ & $\mathbf{K}$ & $\mathbf{S}$ \\
\hline Wheat straw & 42.75 & 0.48 & 89 & 0.25 & 0.59 & 0.12 \\
\hline Cotton Stalk & 44.02 & 0.55 & 80 & 0.19 & 0.61 & 0.09 \\
\hline Sorghum Stubbles & 46.66 & 0.48 & 97 & 0.23 & 1.08 & 0.13 \\
\hline Glyricidia & 38.71 & 1.19 & 33 & 0.30 & 1.21 & 0.16 \\
\hline
\end{tabular}

Table.3 Effect on $\mathrm{pH}$ as influenced by various crop residues during periodic decomposition

\begin{tabular}{|c|c|c|c|c|c|c|}
\hline \multirow{3}{*}{\multicolumn{2}{|c|}{ Treatments }} & \multirow{2}{*}{\multicolumn{5}{|c|}{$\begin{array}{c}\text { pH } \\
\text { Days after decomposition }\end{array}$}} \\
\hline & & & & & & \\
\hline & & \multirow{2}{*}{$\begin{array}{c}\mathbf{1 5}^{\mathbf{D}} \\
\mathbf{7 . 7 8}\end{array}$} & \multirow{2}{*}{$\begin{array}{c}\text { ys afte } \\
\mathbf{3 0} \\
7.48\end{array}$} & \multirow{2}{*}{\begin{tabular}{|c|}
60 \\
7.45
\end{tabular}} & \multirow{2}{*}{$\begin{array}{c}90 \\
7.45\end{array}$} & \multirow{2}{*}{$\begin{array}{l}\mathbf{1 2 0} \\
7.38\end{array}$} \\
\hline $\mathbf{T}_{1}$ & $100 \% \mathrm{WS}$ & & & & & \\
\hline $\mathbf{T}_{2}$ & $100 \%$ SCS & 7.83 & 7.43 & 7.43 & 7.44 & 7.43 \\
\hline $\mathbf{T}_{3}$ & $50 \% \mathrm{WS}+50 \% \mathrm{SCS}$ & 7.89 & 7.48 & 7.58 & 7.05 & 7.48 \\
\hline $\mathbf{T}_{4}$ & $40 \%$ WS $+40 \%$ SCS $+20 \%$ Glyricidia Leaf & 7.52 & 7.16 & 7.19 & 7.14 & 7.16 \\
\hline $\mathbf{T}_{5}$ & $30 \%$ WS $+30 \%$ S C S $+20 \%$ Glyricidia Leaf $+20 \%$ sorghum Stubbles & 7.65 & 7.32 & 7.38 & 7.39 & 7.32 \\
\hline & $25 \%$ W S $+25 \%$ SCS $+25 \%$ Glyricidia Leaf $+25 \%$ sorghum stubbles & 7.61 & 7.23 & 7.30 & 7.27 & 7.23 \\
\hline \multicolumn{2}{|r|}{ (2) } & 0.010 & 0.010 & 0.012 & 0.20 & 0.51 \\
\hline \multicolumn{2}{|c|}{ CD at $5 \%$} & 0.031 & 0.030 & 0.036 & NS & NS \\
\hline
\end{tabular}

Table.4 Effect on total organic carbon content as influenced by various crop residues during periodic decomposition

\begin{tabular}{|c|c|c|c|c|c|c|}
\hline \multirow{2}{*}{\multicolumn{2}{|c|}{ Treatments }} & \multicolumn{5}{|c|}{$\begin{array}{l}\text { Total Organic Carbon (\%) } \\
\text { Days after decomposition }\end{array}$} \\
\hline & & 15 & 30 & 60 & 90 & 120 \\
\hline$T_{1}$ & $100 \% \mathrm{WS}$ & 42.07 & 39.66 & 36.34 & 32.26 & 26.72 \\
\hline $\mathbf{T}_{2}$ & $100 \%$ SCS & 46.09 & 41.57 & 38.92 & 34.28 & 28.14 \\
\hline $\mathbf{T}_{3}$ & $50 \% \mathrm{WS}+50 \% \mathrm{SCS}$ & 47.09 & 40.38 & 37.13 & 33.52 & 26.70 \\
\hline $\mathbf{T}_{4}$ & $40 \%$ WS $+40 \%$ SCS $+20 \%$ Glyricidia Leaf & 40.04 & 37.86 & 33.43 & 29.18 & 24.05 \\
\hline $\mathbf{T}_{5}$ & $30 \% \mathrm{WS}+30 \%$ SCS $+20 \%$ Glyricidia Leaf $+20 \%$ sorghum Stubbles & 41.01 & 38.91 & 35.54 & 30.81 & 25.65 \\
\hline $\mathbf{T}_{6}$ & $25 \%$ W S+25 \%SCS $+25 \%$ Glyricidia Leaf $+25 \%$ sorghum stubbles & 40.06 & 38.86 & 34.75 & 29.66 & 24.92 \\
\hline \multicolumn{2}{|c|}{ SE(m) \pm} & 0.831 & 1.38 & 0.008 & 0.007 & 0.006 \\
\hline \multicolumn{2}{|c|}{ CD at $5 \%$} & 2.488 & NS & 0.023 & 0.022 & 0.019 \\
\hline
\end{tabular}


Table.5 Effect on total nitrogen content as influenced by various crop residues during periodic decomposition

\begin{tabular}{|c|c|c|c|c|c|c|}
\hline \multirow{3}{*}{\multicolumn{2}{|c|}{ Treatments }} & \multirow{2}{*}{\multicolumn{5}{|c|}{$\begin{array}{c}\text { Total nitrogen }(\%) \\
\text { Days after decomposition }\end{array}$}} \\
\hline & & & & & & \\
\hline & & \multirow{2}{*}{$\begin{array}{c}15 \\
0.54\end{array}$} & \multirow{2}{*}{$\begin{array}{c}\text { ays aft } \\
30 \\
0.63\end{array}$} & \multirow{2}{*}{$\begin{array}{c}60 \\
0.71\end{array}$} & \multirow{2}{*}{$\begin{array}{c}90 \\
0.84\end{array}$} & \multirow{2}{*}{$\begin{array}{l}\mathbf{1 2 0} \\
1.01\end{array}$} \\
\hline$T_{1}$ & $100 \% \mathrm{WS}$ & & & & & \\
\hline $\mathbf{T}_{2}$ & $100 \%$ SCS & 0.56 & 0.68 & 0.78 & 0.90 & 1.06 \\
\hline $\mathbf{T}_{3}$ & $50 \% \mathrm{WS}+50 \% \mathrm{SCS}$ & 0.55 & 0.65 & 0.73 & 0.86 & 1.03 \\
\hline $\mathbf{T}_{4}$ & $40 \%$ WS $+40 \%$ SCS $+20 \%$ Glyricidia Leaf & 0.68 & 0.78 & 0.86 & 0.96 & 1.14 \\
\hline $\mathbf{T}_{5}$ & $\begin{array}{l}30 \% \text { WS }+30 \% \text { S C S }+20 \% \text { Glyricidia Leaf }+20 \% \text { sorghum } \\
\text { Stubbles }\end{array}$ & 0.60 & 0.71 & 0.79 & 0.91 & 1.10 \\
\hline $\mathbf{T}_{6}$ & $\begin{array}{l}25 \% \text { W S+25 \%SCS+25\% Glyricidia Leaf }+25 \% \text { sorghum } \\
\text { stubbles }\end{array}$ & 0.77 & 0.85 & 0.92 & 1.02 & 1.19 \\
\hline \multicolumn{2}{|c|}{ SE $(m) \pm$} & 0.024 & 0.007 & 0.007 & 0.008 & 0.007 \\
\hline \multicolumn{2}{|c|}{ CD at $5 \%$} & 0.073 & 0.021 & 0.022 & 0.024 & 0.022 \\
\hline
\end{tabular}

Table.6 Effect on C: N Ratio content as influenced by various crop residues during periodic decomposition

\begin{tabular}{|c|c|c|c|c|c|c|}
\hline \multirow{3}{*}{\multicolumn{2}{|c|}{ Treatments }} & \multirow{2}{*}{\multicolumn{5}{|c|}{$\begin{array}{c}\text { C: N Ratio (\%) } \\
\text { Days after decomposition }\end{array}$}} \\
\hline & & & & & & \\
\hline & & \multirow{2}{*}{$\begin{array}{c}15 \\
79.18\end{array}$} & \multirow{2}{*}{$\begin{array}{c}30 \\
62.92\end{array}$} & \multirow{2}{*}{$\begin{array}{c}60 \\
51.18\end{array}$} & \multirow{2}{*}{$\begin{array}{c}\mathbf{9 0} \\
38.40\end{array}$} & \multirow{2}{*}{$\begin{array}{c}120 \\
26.45\end{array}$} \\
\hline $\mathbf{T}_{1}$ & $100 \% \mathrm{WS}$ & & & & & \\
\hline $\mathbf{T}_{\mathbf{2}}$ & $100 \%$ SCS & 84.78 & 61.14 & 49.89 & 38.08 & 26.55 \\
\hline $\mathbf{T}_{3}$ & $50 \% \mathrm{WS}+50 \% \mathrm{SCS}$ & 82.33 & 62.13 & 50.87 & 38.98 & 25.92 \\
\hline $\mathbf{T}_{4}$ & $40 \%$ WS $+40 \%$ SCS $+20 \%$ Glyricidia Leaf & 59.83 & 48.54 & 38.88 & 30.39 & 21.10 \\
\hline $\mathbf{T}_{5}$ & $\begin{array}{l}30 \% \text { WS }+30 \% \text { S C S }+20 \% \text { Glyricidia Leaf }+20 \% \text { sorghum } \\
\text { Stubbles }\end{array}$ & 69.40 & 54.80 & 44.98 & 33.86 & 23.32 \\
\hline $\mathbf{T}_{6}$ & $25 \% \mathrm{~W}$ S $+25 \% \mathrm{SCS}+25 \%$ Glyricidia Leaf $+25 \%$ sorghum stubbles & 52.90 & 45.71 & 37.77 & 29.07 & 20.94 \\
\hline \multicolumn{2}{|c|}{$\mathrm{SE}(\mathrm{m}) \pm$} & 3.124 & 2.023 & 0.414 & 0.297 & 0.168 \\
\hline \multicolumn{2}{|c|}{ CD at $5 \%$} & 9.345 & 6.057 & 1.241 & 0.888 & 0.503 \\
\hline
\end{tabular}

Table.7 Effect on total phosphorous as influenced by various crop residues during periodic decomposition

\begin{tabular}{|c|c|c|c|c|c|c|}
\hline \multirow{2}{*}{\multicolumn{2}{|c|}{ Treatments }} & \multicolumn{5}{|c|}{$\begin{array}{l}\text { Total Phosphorous (\%) } \\
\text { Days after decomposition }\end{array}$} \\
\hline & & 15 & 30 & 60 & 90 & 120 \\
\hline $\mathbf{T}_{1}$ & $100 \% \mathrm{WS}$ & 0.87 & 0.92 & 1.21 & 1.65 & 1.76 \\
\hline $\mathbf{T}_{2}$ & $100 \%$ SCS & 0.83 & 0.88 & 1.14 & 1.60 & 1.69 \\
\hline $\mathbf{T}_{3}$ & $50 \% \mathrm{WS}+50 \% \mathrm{SCS}$ & 0.85 & 0.91 & 1.18 & 1.61 & 1.71 \\
\hline $\mathbf{T}_{4}$ & $40 \%$ WS $+40 \%$ SCS $+20 \%$ Glyricidia Leaf & 0.99 & 1.18 & 1.44 & 1.78 & 2.05 \\
\hline $\mathbf{T}_{5}$ & $\begin{array}{l}30 \% \mathrm{WS}+30 \% \mathrm{~S} \mathrm{C} \mathrm{S}+20 \% \text { Glyricidia Leaf }+20 \% \text { sorghum } \\
\text { Stubbles }\end{array}$ & 0.91 & 0.98 & 1.32 & 1.68 & 1.82 \\
\hline $\mathbf{T}_{6}$ & $25 \%$ W S $+25 \%$ SCS $+25 \%$ Glyricidia Leaf $+25 \%$ sorghum stubbles & 0.94 & 1.09 & 1.39 & 1.71 & 1.86 \\
\hline \multicolumn{2}{|c|}{$\mathrm{SE}(\mathbf{m}) \pm$} & 0.009 & 0.011 & 0.063 & 0.014 & 0.019 \\
\hline \multicolumn{2}{|c|}{ CD at $5 \%$} & 0.028 & 0.034 & 0.190 & 0.042 & 0.056 \\
\hline
\end{tabular}


Table.8 Effect on total potassium as influenced by various crop residues during periodic decomposition

\begin{tabular}{|c|c|c|c|c|c|c|}
\hline \multirow{3}{*}{\multicolumn{2}{|c|}{ Treatments }} & \multirow{2}{*}{\multicolumn{5}{|c|}{$\begin{array}{c}\text { Total Potassium }(\%) \\
\text { Days after decomposition }\end{array}$}} \\
\hline & & & & & & \\
\hline & & 15 & 30 & 60 & 90 & 120 \\
\hline $\mathbf{T}_{1}$ & $100 \% \mathrm{WS}$ & 0.61 & 0.63 & 0.66 & 0.68 & 0.77 \\
\hline $\mathbf{T}_{2}$ & $100 \%$ SCS & 0.67 & 0.68 & 0.71 & 0.77 & 0.83 \\
\hline $\mathbf{T}_{3}$ & $50 \% \mathrm{WS}+50 \% \mathrm{SCS}$ & 0.63 & 0.65 & 0.66 & 0.72 & 0.74 \\
\hline $\mathbf{T}_{4}$ & $40 \%$ WS $+40 \%$ SCS + $20 \%$ Glyricidia Leaf & 0.80 & 0.80 & 0.85 & 0.87 & 0.93 \\
\hline $\mathbf{T}_{5}$ & $\begin{array}{l}30 \% \text { WS }+30 \% \text { S C S +20 \% Glyricidia Leaf }+20 \% \\
\text { sorghum Stubbles }\end{array}$ & 0.81 & 0.81 & 0.85 & 0.91 & 0.96 \\
\hline $\mathbf{T}_{6}$ & $\begin{array}{l}25 \% \text { W S }+25 \% \text { SCS }+25 \% \text { Glyricidia Leaf }+25 \\
\% \text { sorghum stubbles }\end{array}$ & 0.85 & 0.85 & 0.90 & 0.94 & 0.98 \\
\hline \multicolumn{2}{|c|}{$\mathrm{SE}(\mathrm{m}) \pm$} & 0.011 & 0.011 & 0.010 & 0.011 & 0.011 \\
\hline \multicolumn{2}{|c|}{ CD at $5 \%$} & 0.034 & 0.032 & 0.030 & 0.034 & 0.033 \\
\hline
\end{tabular}

Table.9 Effect on total sulphur as influenced by various crop residues during periodic decomposition

\begin{tabular}{|c|c|c|c|c|c|c|}
\hline \multirow{2}{*}{\multicolumn{2}{|c|}{ Treatments }} & \multicolumn{5}{|c|}{$\begin{array}{c}\text { Sulphur (\%) } \\
\text { Davs after decomposition }\end{array}$} \\
\hline & & \multicolumn{2}{|c|}{$15 \quad \begin{array}{l}\text { Days aft } \\
15\end{array}$} & \multirow{2}{*}{$\begin{array}{c}60 \\
0.26\end{array}$} & \multirow{2}{*}{$\begin{array}{c}90 \\
0.34\end{array}$} & \multirow{2}{*}{$\begin{array}{l}120 \\
0.36\end{array}$} \\
\hline $\mathbf{T}_{1}$ & $100 \% \mathrm{WS}$ & 0.16 & 0.21 & & & \\
\hline $\mathbf{T}_{2}$ & $100 \%$ SCS & 0.11 & 0.16 & 0.23 & 0.31 & 0.33 \\
\hline $\mathbf{T}_{3}$ & $50 \% \mathrm{WS}+50 \% \mathrm{SCS}$ & 0.14 & 0.18 & 0.27 & 0.32 & 0.34 \\
\hline $\mathbf{T}_{4}$ & $40 \%$ WS $+40 \%$ SCS $+20 \%$ Glyricidia Leaf & 0.18 & 0.26 & 0.29 & 0.41 & 0.49 \\
\hline $\mathbf{T}_{5}$ & $\begin{array}{l}30 \% \text { WS }+30 \% \text { SCS }+20 \% \text { Glyricidia Leaf } \\
+20 \% \text { sorghum Stubbles }\end{array}$ & 0.19 & 0.26 & 0.31 & 0.44 & 0.51 \\
\hline$T_{6}$ & $\begin{array}{l}25 \% \mathrm{WS}+25 \% \text { SCS }+25 \% \text { Glyricidia Leaf }+ \\
25 \% \text { sorghum stubbles }\end{array}$ & 0.21 & 0.29 & 0.35 & 0.49 & 0.57 \\
\hline \multicolumn{2}{|c|}{$\mathrm{SE}(\mathrm{m}) \pm$} & 0.009 & 0.008 & 0.010 & 0.010 & 0.009 \\
\hline \multicolumn{2}{|c|}{ CD at $5 \%$} & 0.027 & 0.025 & 0.031 & 0.028 & 0.027 \\
\hline
\end{tabular}

Increase in total $\mathrm{P}$ content due to addition of rock phosphate during composting was also noticed by Biswas and Narayanasamy (2006). Sharif et al., (2013) concluded that the availability of $\mathrm{P}$ from rock phosphate can be enhanced by the organic acids released during composting which might be due to the biological treatments. Perusal of the results presented in Table 8 indicates the significant changes in total potassium content during composting.
The range of total potassium content varied from 0.74 to 0.98 in various treatments the significantly highest value of total potassium content (0.98) is found in (T6) $25 \%$ Wheat straw $+25 \%$ Shredded cotton stalk $+25 \%$ Glyricidia Leaf $+25 \%$ sorghum stubbles followed by (T5) $30 \%$ Wheat Straw +30\% Shredded Cotton Stalk +20\% Glyricidia Leaf $+20 \%$ sorghum Stubbles. Significantly lower potassium content (0.74) was observed in 50:50 combinations of wheat straw and 
shredded cotton stalk. It is quite evident from the data that total potassium contents were significantly increased during composting with time span. Where ever the use of glyricidia leaf was incorporated along with different ratio with wheat straw, Shredded Cotton Stalk and sorghum stubbles the increase in total potassium content was observed. This effect is might be due to higher concentration of potassium in glyricidia leaf and sorghum stubbles.

The results are in close agreement with findings with Patra and Bandyopadhyay (2010). They studied that increase in potash content is due to progressive increase in decomposition of organic matter in the compost heap.

The data presented in Table 9 revealed that Sulphur content of prepared Compost the range of total sulphur content varied from 0.33 to 0.57 in various treatments the significantly highest value of total sulphur content (0.57) is found in (T6) $25 \%$ Wheat straw $+25 \%$ Shredded cotton stalk $+25 \%$ Glyricidia Leaf $+25 \%$ sorghum stubbles. Followed by (T5) $30 \%$ Wheat Straw $+30 \%$ Shredded Cotton Stalk $+20 \%$ Glyricidia Leaf $+20 \%$ sorghum Stubbles. Significantly lower potassium content (0.33) was observed in 100 $\%$ shredded cotton stalk.

It is quite evident from the data that total potassium contents were significantly increased during composting with time span. Where ever the use of glyricidia leaf was incorporated along with different ratio with wheat straw, Shredded Cotton Stalk and sorghum stubbles the increase in total potassium content was observed.

This effect is might be due to higher concentration of potassium in glyricidia leaf. The increase in total $\mathrm{S}$ and available $\mathrm{S}$ was reported by Saha and Hajara (2001).
The $\mathrm{pH}$ was decreased as the decomposition progressed. The significantly highest $\mathrm{pH}$ (7.89) was recorded at 15 days decomposition stage in (T3) that is 50:50 ratios of both wheat straw and shredded cotton stalk. Whereas, least (7.16) was recorded at final stage of decomposition in (T4) $40 \%$ Wheat straw + $40 \%$ Shredded Cotton stalk $+20 \%$ Glyricidia leaf.

The total organic carbon was decreased with time span and decomposition. The higher value (47.09) was recorded for (T3) 50 $\%$ Wheat straw $+50 \%$ Shredded Cotton stalk at 15 days stage.

At the end of composting the lower organic carbon content (24.05) was noted in (T4) 40 $\%$ Wheat straw $+40 \%$ Shredded Cotton stalk $+20 \%$ Glyricidia leaf. However, this treatment found better among other.

The total $\mathrm{N}$ was increased with decomposition period increased. The total $\mathrm{N}$ was observed lowest in $100 \%$ wheat straw as compared to other throughout decomposition period. However, significantly highest total N (1.19) was recorded in (T6) $25 \%$ Wheat straw +25 $\%$ Shredded Cotton stalk $+25 \%$ Glyricidia leaf $+25 \%$ sorghum stubble. Followed by in (T4) $40 \%$ Wheat Straw $+40 \%$ Shredded Cotton Stalk $+20 \%$ Glyricidia Leaf.

At 15 days of Composting, the C: $\mathrm{N}$ ratio ranged between 52.90 to 84.78 which were gradually decreased to 20.94 to 26.55 at 120 days. At the end of Compost, the compost prepared from $25 \%$ Wheat straw +25 $\%$ Shredded cotton stalk $+25 \%$ Glyricidia Leaf $+25 \%$ sorghum stubbles recorded the lowest $\mathrm{C}: \mathrm{N}$ ratio (20.94) followed by compost obtaining from $40 \%$ Wheat Straw $+40 \%$ Shredded Cotton Stalk $+20 \%$ Glyricidia Leaf (21.10) treatment. While, the highest $\mathrm{C}: \mathrm{N}$ ratio (26.55) was recorded with $100 \%$ Shredded Cotton Stalk (T2). 
The total phosphorus which was ranged between 0.83 to 0.99 at the starts of composting. It increases at subsequent stages of decomposition.

The significantly highest value (2.05) recorded at final stage of decomposition in this treatment (T4) 40\% Wheat Straw +40\% Shredded Cotton Stalk $+20 \%$ Glyricidia Leaf. The lowest P content $(0.83 \%)$ observed at 15 days stage

Total potassium contents were significantly increased during composting with time span. Where ever the use of glyricidia leaf was incorporated along with equal quantity of wheat straw, Shredded Cotton Stalk and sorghum stubbles the increase in total potassium content was observed. The significantly highest total $\mathrm{K}$ (0.98) was recorded at 120 days decomposition stage in T6.

Whereas, least (0.61) was recorded 15 days stage of decomposition in (T1) $100 \%$ Wheat straw.

The significantly highest sulphur (0.57) was recorded at 120 days decomposition stage in T6. Whereas, lower (0.11) was recorded 15 days stage of decomposition in (T1) $100 \%$ shredded cotton stalk.

The (T6) $25 \%$ Wheat straw +25\% Shredded cotton stalk $+25 \%$ Glyricidia Leaf $+25 \%$ sorghum stubbles was found better among other combination of crop residues.

\section{References}

Banta, G. and Dev, S. P. 2009. Field evaluation of nitrogen enriched phosphocompost prepared from green biomass of Lantana camara in wheat. Indian J. Ecology. 36(1): 39-44.

Biswas, D.R and G. Narayansamy, 2006. Rock phosphate enriched compost: An approach to improve low-grade Indian rock phosphate. Bioresource Tchnology, 97: 2243-2251.

Khan, M. and Sharif, M. 2012. Solubility enhancement of phosphorus from rock phosphate through composting with poultry litter. Sarhad J. Agric. 28(3): 415420.

Manna, M. C., J. N. Hajra and A. B. Singh., 2001. Comparative effectiveness of enriched phosphocompost and chemical fertilizer on crop yields and soil biological activity in an alluvial soil. Indian J. Agric. Res., 35(4): 247-250.

Patra, S and S. Bandyopadhyay.2010. Preparation of phosphorus enriched compost: Effect of rock phosphate and microbial inoculums. Green Farming. 1(6): 580-583.

Saha H. and Hajra, J. N. 2001.Preparation of phosphocompost from rice straw and response of groundnut. J. of Ind. Soc. of Soil Sci. 49(1):144-149.

Sharif, S., Burni, T., Wahid, F., Khan, F., Khan, S., Khan, A. and Shah, A. 2013. Effect of rock phosphate composted with organic materials on yield and phosphorus uptake of wheat and mung bean crops. Pak. J. Bot., 45(4): 1349-1356.

Sibi, G. 2011. Role of phosphate solubilizing fungi during phosphocompost production and their effect on the growth of tomato (Lycopersicon esculentum L) plants. J. of App. and Natural Sci., 3 (2): 287-290.

Singh, C. P. and Amberger, A. 1998. Organic acids and phosphorus solubilization in straw composted with rock phosphate. J. of Bioresourcr Tech., 63:13-16.

\section{How to cite this article:}

Priyanka N. Daphal, P.W. Deshmukh and Rahul J. Patil. 2019. Assessment of Changes in Various Chemical Properties during Decomposition of Crop Residues. Int.J.Curr.Microbiol.App.Sci. 8(11): 2546-2554. doi: https://doi.org/10.20546/ijcmas.2019.811.294 